\title{
Koncept održivog razvoja kroz prizmu Božjeg kraljevstva
}

\author{
Dalia Matijević \\ Crkva Isusa iz Nazareta \\ daliamatijevic@gmail.com
}

UDK: 27-23:27-4:502.13

Izvorni znanstveni članak

https://doi.org/10.32862/k1.14.2.5

\section{Sažetak}

Istražujući poveznice između dva naizgled inkompatibilna koncepta, Božjeg kraljevstva i održivog razvoja, pokušat ćemo ih promotriti paralelno, a dobivene rezultate iskoristiti tako da uvidimo mogu li se ova dva koncepta međusobno podržavati. Cilj nam je bolje razumjeti buduće perspektive koje se otvaraju pred Crkvom u suvremenom kontekstu. Dva, ovdje razmatrana koncepta nikad nisu niti trebala biti razdvojena. Iako dolaze iz različitih izvora, koriste drugačiji izričaj te izrastaju iz dva vrlo različita sociopolitička konteksta, oni se ipak bave istim univerzalno važnim pitanjima. Za oba koncepta vrijedi da se željno iščekuje njihovo ostvarenje, oba su od ključne važnosti, oba pozivaju na duboku osobnu i kolektivnu transformaciju, oba pretpostavljaju snažnu afirmaciju kreativnosti i inovativnosti, oba predmnijevaju značajan kapacitet mobiliziranja zajednica, ljudi i dobara. Preklapanja između održivog razvoja i Božjeg kraljevstva omogućavaju Crkvi da u svijetu praktično primjenjuje shalom i njeguje hesed, potičući i razvijajući duh prihvaćanja drugog, dosljedno lobirajući za socijalnu pravednost, brinući se o siromašnima i marginaliziranima te šireći ljubav i suosjećanje na Božje stvorenje u cjelini, ne ovaj put bez gubljenja svoga izvornog identiteta. U kontekstu praktične primjene načela održivog razvoja, uloga je Crkve osigurati da nitko ne bude izostavljen ili zanemaren. Crkva bi, zapravo, mogla biti najbolji dio prakse održivog razvoja, upravo svojim upornim inzistiranjem na istom skupu univerzalnih vrijednosti Božjeg kraljevstva, bez obzira na to kako se mijenjaju okolnosti.

Ključne riječi: Božje kraljevstvo, održivi razvoj, osobna i kolektivna transformacija, shalom, hesed 


\section{Uvod}

Živimo u vremenu kompleksne krize koja zahvaća cijeli svijet. Riječ je o krizi s puno lica: kriza života, kriza svekolike degradacije kapaciteta za mir, kriza dominantnog sustava mišljenja, koji poticanjem konzumerističkog i relativističkog svjetonazora uzrokuje nepopravljivu štetu za sve, kriza koja milijunima ljudi donosi glad i duboko siromaštvo, a sve usred kvalitetno orkestriranih napora, usmjerenih na zaustavljanje širenja masovne bijede čovječanstva. Radi se također o krizi otrežnjavajućeg suočavanja s klimatskim promjenama i s činjenicom iscrpljenih prirodnih dobara, o krizi znanja i zdravlja, krizi ljudskosti. Stoga, jasna je naša duboka potreba ponovnog konstruktivnog preispitivanja životvornog koncepta Božjeg kraljevstva kako bismo imali priliku iznova učiti iz toga nepresušnog izvora.

Tvrdnja od koje krećemo u ovom članku jest da koncept Božjeg kraljevstva predmnijeva ključnu strukturu, metodologiju, preduvjete, karakteristike i dinamiku koje bi svaki dugoročni smisleni razvojni plan trebao ozbiljno uzeti u obzir, pod uvjetom da njegovi autori pretpostavljaju uspješnost. U tom kontekstu, globalno prihvaćeni okvir održivog razvoja (OR), posebice njegov dio koji se odnosi na Agendu 2030 i 17 pripadajućih ciljeva održivog razvoja (COR-ovi), predstavlja vrijedan reprezentativan primjer. $U$ ovom ćemo radu pokazati kako ova globalna inicijativa pretpostavlja mnoge važne odrednice Božjeg kraljevstva te ju kao takvu Crkva treba uzeti sasvim ozbiljno u obzir unatoč činjenici da potiče isključivo iz sekularne sfere djelovanja. Namjera nam je argumentirano ustvrditi kako je prijeko potrebno da Crkva usvoji svjež način razumijevanja svoje misije te da trajno i aktivno promišlja o tome što zapravo znači djelovati misijski i biti smisleno uključen u dinamiku suvremenog svijeta. Pitanja na koja ćemo ovdje pokušati odgovoriti su:

Koji je odnos između dva koncepta: Božjeg kraljevstva i održivog razvoja?

Kako se oni međusobno razlikuju te imaju li sličnosti? Mogu li se međusobno podržavati i nadopunjavati?

Na koji je način koncept OR-a relevantan za Crkvu?

Kako možemo razumjeti poslanje Crkve ako ga promatramo kroz prizmu paradigme održivog razvoja?

Kako bismo bolje istražili moguće odgovore, paralelno ćemo promatrati dva naizgled nespojiva koncepta, Božje kraljevstvo i OR, kako bismo utvrdili mogu li oni međusobno surađivati te se po mogućnosti nadalje razvijati kroz takvu suradnju. Svrha je dovesti kršćansku i sekularnu sferu u smislenu korelaciju, posebice u kontekstu istraživanja i iznalaženja novih načina štovanja Boga na koherentan i cjelovit način, bez kompromitiranja kršćanskog identiteta. Božji plan izmirenja svega stvorenog sa svojim Stvoriteljem svakako uključuje aktivno sudjelovanje 
Crkve. U tom bismo kontekstu rado vidjeli Crkvu koja smjelo afirmira „cijeli svijet kao svoju župu“. ${ }^{1}$

\section{Razumijevanje terminologije}

\section{Božje kraljevstvo}

Božje kraljevstvo, ili Matejev sinonim Nebesko kraljevstvo, hebrejski malku$t h^{2}$ i grčki basileia tou theou, kao i drugi oblici koji proizlaze iz navedenih termina, predstavlja apstraktan pojam koji se može odnositi na teritorij, vladanje, kraljevsku vlast, suverenitet itd. Predstavlja Božji atribut i model Božjeg djelovanja. Charles Dodd $(1961,24)$ je svojevremeno ovaj pojam dobro pojasnio kao utemeljenu nadu postizanja ultimativnog stanja pravednosti: „ideja vodilja jest da se Božja moć manifestira u sferi ljudskog iskustva, što znači da će osuda stići svako zlo, a blaženstvo i oslobođenje izliti se na sve što je u zajedništvu s Bogom“.

Tijekom duge povijesti promišljanja o Božjem kraljevstvu, upotrebljavala su se dva temeljna načina tumačenja: eshatološki i ne-eshatološki. Eshatološko tumačenje, koje su dosljedno zastupali rani crkveni oci poput Barnabe, Papije, Justina Mučenika, Ireneja i Tertulijana, u najvećoj je mjeri elaborirao Albert Schweitzer koji je bio uvjeren kako je Isusovo učenje u cijelosti apokaliptično. Taj onostrani aspekt Božjeg kraljevstva, koji podrazumijeva žudno iščekivanje da će Bog konačno opravdati svoje ljude, preuzet je, dakako, iz ranog judaizma (Chilton 1984, 7-12). Ne-eshatološko tumačenje pak uglavnom proizlazi iz Augustinove tvrdnje da Crkva na Zemlji zapravo predstavlja samo Božje kraljevstvo. Augustin i njegovi duhovni nasljednici pritom su do određene mjere ignorirali biblijsku postavku da se Božje kraljevstvo prije svega odnosi na nadnaravno Božje djelovanje. Stavljali su poseban naglasak na primjenu etičkih načela Kraljevstva te uživali u ideji afirmacije Božjega kraljevstva među ljudima (Chilton 1984, 13-22).

Stoga, još uvijek imamo potrebu za cjelovito smislenom teološkom sintezom koja bi nam omogućila da Božje kraljevstvo razumijemo kao eshatološku futurističku realnost koja, međutim, ipak snažno natapa i oblikuje našu sadašnjost.

Bruce Chilton $(1984,4)$ smatra da se svi evanđeoski kršćani slažu oko toga da je primarna svrha Isusove službe bila najavljivati, propovijedati i objavljivati Božje kraljevstvo (Mt 4,12-17; 4,23; 9,35; Mk 1,14-15; Lk 4,43; 8,1; 9,11). Iako nas, u nekoliko slučajeva, Isusove izjave o Božjem kraljevstvu mogu ostaviti zbunjene

1 Glasovita uzrečica Johna Wesleyja koju je izrekao kad su ga kritizirali zbog propovijedanja izvan Crkve.

2 Autori Evanđelja se najvjerojatnije referiraju na tekst Izaija 52, kada govore o Božjem kraljevstvu. Izaija 52,7 „Bog tvoj kraljuje (malakh)' je u tijesnoj vezi s 'mir, spasenje, dobra vijest“. 
(primjerice Mk 1,34 ili Mt 26,29), to ipak ne znači da je Isus namjerno govorio o Božjem kraljevstvu na opskurni način. Naprotiv, Isus je govorio o nečemu što je većini njegovih slušatelja bilo dobro poznato i veoma blisko. Židovi 1. stoljeća sanjali su o dolasku Božjeg kraljevstva, očekivali njegovo potpuno ispunjenje te željno iščekivali njegov skori dolazak (Chilton 1984, 6). Izgleda da smo zapravo mi oni kojima izmiče pravi kontekst poruke Božjeg kraljevstva. A možda nam se to događa samo zato što više ne sanjamo Dođi Kraljevstvo Tvoje, barem ne kao sastavni dio našega svakodnevnog življenja.

Isusovo učenje o Božjem kraljevstvu, kao što je zabilježeno u evanđeljima, jednako nas upućuje na budućnost kao i na sadašnjost. Neka od upućivanja na budućnost izgledaju kao da se odnose na tada nadolazeće povijesne događaje, dok neka druga podsjećaju više na vizionarska apokaliptička predskazanja. Upućivanja na budućnost i na sadašnjost međusobno se isprepliću i svakako se u ovom kontekstu možemo složiti s Doddom $(1961,36)$ da razmrsiti ih nije nimalo lak zadatak.

\section{Održivi razvoj}

Održivi razvoj (OR) definira se kao način progresivnog razvoja koji u konačnici zadovoljava potrebe živućih naraštaja, bez ugrožavanja mogućnosti i kapaciteta budućih naraštaja da zadovolje sve svoje životne potrebe. Koncept potreba u ovom kontekstu prelazi granice jednostavnoga materijalnog življenja te predmnijeva vrijednosti, odnose, slobodu mišljenja, djelovanja i sudjelovanja, pri čemu se sve to ostvaruje kroz održivi način življenja, također na etičkoj i duhovnoj razini. ${ }^{3}$ Ovaj koncept izrasta iz nedvojbene potrebe modernog čovjeka da se konstruktivno suoči s kompleksnošću aktualnih problema, perspektiva, vrijednosnih sustava i interesa dok pokušava razumjeti koji je najbolji mogući način daljnjeg razvoja ljudskog društva.

Možda najbolji način cjelovitog razumijevanja ovog koncepta ${ }^{4}$ jest promatrati ga kao otvoreni „dijalog vrijednosti“ te kao praktičan poticaj na trajno i progresivno učenje, rast kapaciteta razmišljanja i poimanja tradicionalnih načina življenja i djelovanja te na samostalno istraživanje sa svrhom zadobivanja nekih novih perspektiva gledanja na rastuće probleme suvremenog svijeta. Cjelokupni se koncept odnosi na zaštitu prirodnog okoliša i dobara putem dosljedne afir-

3 Vidi: https://www.sciencedirect.com/topics/earth-and-planetary-sciences/sustainable-development

4 Pojam OR koristim dinamično kao paradigmu - sveobuhvatni društveni fenomen koji određuje standarde življenja i djelovanja; koncept - apstraktnu ideju ili opći pojam koji pretpostavlja pripadajuća načela; perspektivu - točku gledanja; okvir - ključnu programsku strukturu koja služi kao platforma za razvijanje planova i programa; te skup ciljeva - posebni načini i modeli praktične primjene. 
macije društvene pravde i primjene načela ekonomske pravičnosti. Zapravo se radi o očuvanju i vrednovanju života u njegovoj iskonskoj cjelovitosti. Stoga, a jednako vrijedi i za Božje kraljevstvo, OR je samo naizgled antropocentričan. OR je nedvojbeno i suštinski biocentričan iako nas različiti aspekti praktične primjene u konkretnom kontekstu mogu u tom smislu zbuniti. Također, sam pojam OR-a može djelovati duboko kontradiktorno pošto razvoj najčešće predmnijeva ekonomski rast, dok održivost pretpostavlja život i proizvodnju unutar ekoloških granica (Blewitt 2008, 62). Svjesnim sljubljivanjem pojmova razvoj i održivost, svijet se, dakle, otvara za progresivnu transformaciju.

Važna odrednica sekularnog poimanja OR-a, koju također afirmiraju i mnogi kršćanski lideri, jest odnos između učenja i upravljanja znanjem te inovacijama. U tom smislu, ključnu ulogu pri postizanju OR-a, koji je smislen, praktičan i živo primjenjiv ima transformativno vođenje. ${ }^{5}$ Radi se načinu vodstva koje dosljedno vodi računa o potrebi za kontinuiranim osobnim i profesionalnim rastom (Blewitt 2008, 175-176).

\section{Metodologija, problemi i pitanja}

Namjera je ovog članka razmotriti koncept Božjega kraljevstva kao što je predstavljen u Bibliji, ali specifično vodeći računa o pripadajućim odrednicama i mogućnostima integralnoga društvenog i ekonomskog razvoja ljudskog društva. Paralelno ćemo razmatrati okvir OR-a te potom koristiti dobivene nalaze pri boljem razumijevanju budućih perspektiva koje se otvaraju u suvremenom kontekstu. Naša je pretpostavka da se UN Agenda 2030 sa 17 COR-ova ne može praktično provesti, a da se koncept Božjega kraljevstva ozbiljno ne uzme u obzir. Jasno je da sama ideja Božjega kraljevstva pretpostavlja puno više od suvremene paradigme OR-a te kao takva praktično otvara put oblikovanju društva slobode, poštenja, pravednosti, međusobne odgovornosti, etičnosti i vladavine prava.

Sve članice UN-a provode Agendu 2030 kao projekciju učinkovitog rješenja problema daljnjeg razvoja modernog svijeta, koji ozbiljno pretpostavlja potrebu pravičnog proaktivnog uključivanja i sudjelovanja svih u kompleksnom procesu dosezanja socijalne i ekonomske održivosti za sve. Optimistični plan ispunjavanja 17 COR-ova do 2030. godine zapravo predstavlja nastavak procesa koji je započet još 1992. na Samitu o Zemlji u Rio de Janeiru. U tom su smislu tijekom posljednjih 25 godina mobilizirane ogromne količine svjetskih resursa s ciljem

5 Dinamičan proces koji dovodi do duboke promjene u ljudima i načinu kako oni razumiju svoje životne okolnosti. Transformativno vodstvo podrazumijeva izuzetan oblik utjecaja koji sljedbenike potiče da postižu više od onoga što se obično od njih očekuje (Blewitt 2008, 175176). 
učinkovitog razvoja legislativnog, financijskog, institucionalnog i operativnog provedbenog okvira, čega su rezultati također jasno vidljivi i u našoj zemlji, posebice u smislu institucionalnog razvoja. No unatoč naporima i sredstvima koje je uložila svjetska zajednica, još uvijek može izgledati kao da nema pravog napretka i promjene.

Sigurd Grindheim $(2018,35)$ nas upućuje na biblijsku pretpostavku da Božje kraljevstvo zapravo nije za svakoga: „Ne samo da je teško ući, već je također veoma lako doživjeti da budeš izbačen", a takav se stav jasno suprotstavlja OR konceptu, koji za sebe pretpostavlja univerzalnu uključivost. Takav je stav iz biblijske perspektive nerealan i utopijski, možda upravo stoga što se radi prije svega o ljudskom i humanistički obojenom projektu. Glen Stassen i David Gushee $(2003,54)$ po pitanju dinamike Božjega kraljevstva smatraju da je ono prvenstveno usmjereno na uspostavljanje i gradnju (kvalitetnih) odnosa umjesto da se temelji na transakcijama. Ideja OR-a, svakako, pokušava slijediti taj put. Zapravo, izrazito komunalni patos OR-a snažno upućuje na kršćansku etiku.

Važno je uočiti u kolikoj mjeri nas naše razumijevanje koncepta Božjega kraljevstva oblikuje kao djelatne kršćane, ali se također danas čini jednako važno biti sposoban usvojiti okvir OR-a a da ne osjećamo kako kompromitiramo svoje izvorne kršćanske prioritete. Stoga, pogledajmo na koji je način koncept OR-a relevantan za Crkvu te koji to aspekti Božjega kraljevstva mogu biti posebno od pomoći da ona usvoji provedbeni okvir OR-a kao posebno vrijedan svog angažmana.

\section{Božje kraljevstvo}

Božje/Nebesko kraljevstvo nalazi se u samom središtu Isusove poruke. Pojam predstavlja dominantnu biblijsku metaforu, onu koja je paradoksalno i meta-središnjica i misterij Isusove objave (Perrin 2019, 31). Kao što Jeremy R. Treat (2019, 17) duboko uvjeren tvrdi, Isus je svojim sljedbenicima dao mnogo zapovijedi, ali je za samo jedno rekao da treba tražiti prvo: „Tražite najprije Božje kraljevstvo i njegovu pravdu" (Mt 6,33). Izgleda da to jedno zapravo mijenja sve.

Sam pojam dolazi iz svijeta orijentalnih monarhija te se njegov izvorni kontekst izrazito razlikuje od konteksta modernih svjetskih demokracija. Povijesno gledano, pojam se povezivao s progresivno otkupljenim i ljubavlju nadahnutim društvom; budućom transformacijom svijeta; apokaliptičnom nadom budućega svijeta (Dulling 1992, 4932). Pojam Božje kraljevstvo dolazi doslovce od grčkog

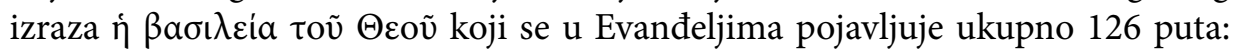
55 puta kod Mateja, 20 puta kod Marka, 46 puta kod Luke, 8 puta u Djelima te 5 puta kod Ivana (Green 2013, 468). Većina tih navoda pretpostavlja ekvivalentnost s Očevim kraljevstvom, Isusovim kraljevstvom i kraljevstvom Sina Čovječjeg. U 
smislu djelovanja, statistički govoreći, u Božje se kraljevstvo najčešće ulazi (npr. Mt 5,20; Mk 9,47; Lk 18,17; Iv 3,5), o njemu se propovijeda (npr. Mt 4,23; 9,35; 10,$7 ; 13,19 ; 24,14$; itd.), za njim se čezne (npr. Mt 6,33; Lk 12,31), željno ga se ǐ̌̌cekuje (npr. Mk 15,43, Lk 23,51), posjeduje ili prima na dar (npr. Mt 5,3; Lk 12,32), ono je poklonjeno (npr. Lk 22,29), nasljeduje se (npr. Mt 8,12; 25,34) ili je oduzeto (npr. Mt 21,43) (Green 213, 468-479).

Danas prevladava mišljenje da Božje/Nebesko kraljevstvo ne predstavlja prostorni, teritorijalni, politički ili nacionalni pojam te ga treba bolje prevoditi kao kraljevanje, vladanje ili suverenitet, umjesto kraljevstvo. Kada je riječ o prevođenju, ne smiju i ne mogu se zanemariti političke, ekonomske i socijalne dimenzije drevnoga orijentalnog kraljevstva. Mnogi su znanstvenici primijetili da engleska fraza Kingdom of God zapravo ne odgovara novozavjetnom grčkom pojmu jer prvenstveno upućuje na fizički prostor, mjesto ili lokalitet, dok se grčki pojam može odnositi na radnju (npr. fenomen Božjeg vladanja). ${ }^{6} \mathrm{U}$ nekim slučajevima izgleda kao da Isus misli na mjesto (Mk 14,25; Lk 13,28), dok se u nekim drugim čini da govori o nečemu što se odnosi na osobno iskustvo vjernika (npr. Mt 6,33). Kad Isus odgovara razapetom lopovu: „Danas ćeš još biti sa mnom u raju" (Lk 23,43), njegov se odgovor referira na prostor s one strane smrti. U Ivanovu se evanđelju pak čini da je ulazak u Kraljevstvo mogućnost u sadašnjosti (3,3-5) (Powell 2011, 690). Očito je da ovdje ne bismo trebali uzeti odabrani tekst te ga učiniti ključnim za tumačenje drugih tekstova. Dale C. Allison Jr. $(2010,22)$ nas s punim pravom upozorava kako bismo trebali moći izbjeći iskušenje poravnavanja različitih tekstova, čime će se odabrani pojam u dva različita teksta dosljedno odnositi na potpuno istu stvar. Ovo je upravo slučaj kada jedno značenje nužno ne isključuje drugo značenje odabranog pojma. Radi se, naime, o višeznačnom pojmu.

Božje kraljevstvo potječe od Boga, od njega dobiva svoj karakter i prethodi svakom ljudskom djelovanju. Tako podržava još jedan važan kršćanski teološki koncept ukorijenjen u arminijanskoj/wesleyjanskoj teologiji - prethodna milost, ${ }^{7}$ koja doprinosi dojmu da je Bog aktivno i dinamično uključen u ljudski život. Ulazak u Kraljevstvo može imati značenje ulaženja u prostor ili mjesto, ali također i ulaženja u sferu ili iskustvo neposredne identifikacije i/ili sudjelovanja. Za Brucea Chiltona, Božje je kraljevstvo prije svega „Božje djelovanje u svijetu“ koje ima sposobnost donošenja dubokih promjena.

Ali kako ono zapravo izgleda? Možemo pročitati da je poput sijača koji ide

6 Hrvatski jezik koristi frazu „Božje kraljevstvo“ za jedinstvenu fizičku i duhovnu sferu u kojoj Bog suvereno vlada, a Njegov suverenitet snažno zahvaća sve aspekte življenja i djelovanja.

7 Engl. Prevenient grace, Božanska milost koja prethodi bilo kojoj ljudskoj odluci i/ili djelovanju te omogućava, ali ne osigurava, osobno prihvaćanje dara spasenja. 
sijati ispunjen nadom i iščekivanjem, da je poput skupocjenog bisera koji tek čeka da bude primjereno cijenjen ili poput sićušnog sjemena gorušice koje ima ogroman kapacitet rasta (Mt 13; Mk 4; Lk 8). Možemo razumjeti ove slike i simboliku istinskih vrijednosti, koje se $s$ vremenom samo povećavaju ako ih pravilno njegujemo i cijenimo. Kako se ulazi u Kraljevstvo te kako se u njemu sudjeluje? Trebamo li prodati sve što imamo pa dati siromašnima ili nam je pak više potrebno da se odmaknemo od dominantnog svjetonazora i postanemo nevini, nekorumpirani i otvoreni poput malog djeteta? Da i da. Ali ima još i više od toga. Je li ulazak u Kraljevstvo važan? Apsolutno! Pa Isus kaže da bi se bilo bolje samoosakatiti nego uopće ne ulaziti (Mt 5,30; Mk 9,43).

\section{Božje kraljevstvo u Starom zavjetu}

Pojam Nebesko kraljevstvo (hebrejski malkût šāmayim) ne koristi se u Starom zavjetu. Međutim, postoje mnogi odlomci koji se odnose na YHVH-a kao kralja, što upućuje da je Bog zamišljen kao kralj koji vlada nad Izraelom, svim narodima i cijelom prirodom. Mnogi biblijski redci potvrđuju da Bog vlada nad svim stvorenim, da se brine za ljude i druga stvorenja te da kroz njih ili u njihovo ime ostvaruje svoje božanske ciljeve (npr. Job 38-39; Ps 104; 145; 147; Jer 45,113; Dan 4,17; Iv 1-4). Također, potvrđuje se da Bog kraljuje u povijesti sudbinom Izraela i drugih naroda, što se posebno može pratiti u psalmima (npr. 22,27-28; 47; 95-99) i Danijelu (4,3.34-35). No Božje kraljevstvo također poprima ulogu osude protiv Izraela, Judeje ili drugih naroda (npr. Jer 1-11; Ezek 12-16; Amos 1,3-4,13) (Powell 2011, 689).

Također, djeluju i neke druge sile koje sprječavaju ispunjenje Božjih zamisli, što se najviše odnosi na iskvarenost Božjeg naroda (npr. Iz 1; 3; 5; Jer 2-8; Hoš 4-10; Amos 2,26-6,13; 8,4-7) te neprijateljstvo drugih naroda (npr. 13,1-19,15; Amos 1,3-2,3). No ne treba zanemariti ni čimbenike sudbine i slučaja (Prop 9,1112). To je razlog da se autori hebrejskih proročkih spisa često raduju budućem vremenu, kada će se na Zemlji uspostaviti Božja vladavina (npr. Obad 21; Hag 2,21-23; Zah 14,9). Novo se doba doživljava kao razdoblje u kojem će svi narodi živjeti u miru i priznavati Gospodina kao svoga suverenog vladara (npr. Iz 2,2-4; 19,19-24; Mih 4,1-3; cf. Zah 14,16-19), dok se u nekim drugim redcima tvrdi da će novo vrijeme biti vrijeme mira i blagoslova za sve stvoreno (npr. Iz 11,6-9; 65,17-25; Hoš 2,18; cf. Ezek 34,25-28). Stoga, iako se pojam Božjeg kraljevstva ne koristi u Starom zavjetu, sama ideja, koja nosi snažni eshatološki i društveni značaj, jasno je prisutna širom hebrejske Biblije.

\section{Božje kraljevstvo u Novom zavjetu}

Isus nije izmislio novi koncept, već je usvojio postojeću, općeprihvaćenu ideju Božje vladavine. Njegove se biblijske afirmacije posebice oslanjaju na psalme (Gospod kao kralj primjenjuje svoj kraljevski suverenitet nad cijelim kozmo- 
som), Ljetopise (vladavina JHVH-a je u izravnoj vezi s Davidovom dinastijom i štovanjem Izraela), Danijela (Božja je vladavina univerzalna i vječna) i druge proroke, posebice na Izaijino iščekivanje završetka progonstva i obnove Izraela putem naviještanja dobre vijesti kao mira i spasenja (npr. Iz 44,1-6) (Green 2011, 471).

Marko uvodi specifičnu vrstu vremenske napetosti: „Božje je kraljevstvo blizu“ (1,15 ili bolje „Božje kraljevstvo se približilo"). Prošlo vrijeme u ovdje upotrijebljenom grčkom glagolu èngiken odnosi se na prošlost s implikacijama u sadašnjosti; ipak se podrazumijeva i budućnost pošto Kraljevstvo još nije prisutno u punom apokaliptičkom smislu (isto u Mk 9,1; 14,25; 15,43) (Dulling 1992, 4942). Ova vremenska napetost također korespondira s prisutnošću Kraljevstva kao tajanstveno skrivenog i nevjernima (poput, primjerice, nositelja religijskih vlasti) neshvatljivog, ali vjernima razotkrivenog $(4,11)$. Sljedećih šest izreka o kraljevstvu, koje se pojavljuju u središnjem dijelu teksta $(9,47 ; 10,14,15 ; 10,23,24$, 25), daju živopisne ilustracije o tome kakav je duhovni stav potreban za ulazak u Kraljevstvo (biti bez grijeha, nevin kao dijete, slobodan od materijalnih vezanosti). Nadalje, Zakon shvaćen kao ljubav prema Bogu i bližnjemu (Marko 12,34), svemu dodaje etičku vrijednost. Ukratko, Marko koristi izreke o Kraljevstvu koje sve pretpostavljaju jasne eshatološke $(9,1 ; 14,25)$, kristološke $(1,15)$ i komunalne aspekte $(4,11)$ (Dulling 1992, 4942-3).

Matej stavlja poseban naglasak na propovijedanje Evanđelja Kraljevstva. Isus je prije svega propovjednik i učitelj Evanđelja Kraljevstva $(10,7 ; 28,20)$, ali istovremeno i samo Kraljevstvo svjedoči o Isusu $(24,14 ; 26,13)$. Kraljevstvo se očekuje u sadašnjosti koja teče iz prošlosti i prelijeva se u budućnost. Ono je, stoga, vremensko u bivanju eshatološkim i kristološkim, ali je također i prostorno pošto dolazi s Isusom. Također je i etično, jer su preduvjeti za ulazak u Kraljevstvo ukorijenjeni u etici, s Isusom i Ivanom kao uzorima (Dulling 1992, 4944-5). Ovo, najizrazitije židovsko od sva četiri kanonska evanđelja, na jedinstven način koristi izraz „Kraljevstvo nebesko“, vjerojatno se referirajući na Daniel 2-7, gdje se izrazito afirmira presudna razlika između svakoga zemaljskog i nebeskog kraljevstva. Budući da je jedini evanđelist koji koristi pojam ekklēsia, Matej tako snažno afirmira pitanje odnosa između nebeskog Kraljevstva i Crkve (16,18-19) (Green 2011, 6571).

Luka i knjiga Djela apostolskih afirmiraju ključnu potrebu objavljivanja Kraljevstva i neposrednog življenja njegovih načela zato što ih je Isus svakodnevno živio. Ipak, naglasak je na mnogim nevoljama / progonima, što upućuje na milosrdnu brigu o političkim, socijalnim i ekonomskim realnostima kršćanskog življenja, posebno kad su u pitanju žene, siromašni, bolesni, zatvorenici i druge marginalizirane društvene skupine. Luka se bavi politikom Božjega kraljevstva te ga zanima narav i raspodjela moći. Politika Kraljevstva distancira se od političke 
igre koja se odvija pod rimskim uvjetima, a umjesto toga okreće se obvezama društva prema potrebitima i siromašnima (Green 2013, 6574).

U Ivanovim tekstovima nalazimo 15 neposrednih referenci te jednu koja se samo posredno odnosi na Isusa kao kralja. Ipak, većina ih ima upitni ili ironični smisao. U Ivan 18,36 Isus odgovara na Pilatovo pitanje o njegovu političkom statusu kralja: „Moje kraljevstvo nije od ovoga svijeta“. Ovo tipično ivanovsko gledište može jednostavno odražavati sektaški stav koji naglašava ne-zemaljsku realnost, ali ono zasigurno i danas oblikuje naše suvremeno viđenje Kraljevstva kao onoga koje nema ništa zajedničko sa svjetovnim (Dulling 1992, 4948). Knjiga Otkrivenja je prožeta izrazitom kraljevskom simbolikom $(21,1-22,5)$, a nebeski Jeruzalem je izjednačen s kozmičkim Božjim kraljevstvom (Dulling 1992, 4957).

Pavao ukazuje na napetost koja postoji između sadašnjeg Kraljevstva Krista / Boga čije se ostvarenje željno iščekuje i budućeg apokaliptičkog konačnog ostvarenja Božjega kraljevstva. Budući da kontekst Pavlovih tekstova često podrazumijeva krštenje, stav je mnogih poznavatelja ove materije da je Pavao zapravo u tim tekstovima vjerojatno pokušao obnoviti tradicije krštenja (Dulling 1992, 4955-6).

Neki su teolozi smatrali da treba otvoriti pitanje do koje je mjere Isusova objava Božjega kraljevstva zapravo predstavljala njegov politički stav te koje su moguće političke implikacije u tom kontekstu. Richard A. Horsley tvrdi da je Isusov poziv na obnovu zavjeta bio neodvojiv od njegove proročke osude carske vladavine Rima (Green 2013, 6565). Isus se zalagao za Božju obnovu u ekonomskom, društvenom i političkom smislu, a ne isključivo u duhovnom, eteričnom ili vjerskom. Međutim, usred nepovoljne društvene stvarnosti judaizma drugog Hrama, objavljivanje Kraljevstva naposljetku se izrazitije pomaknulo u eterične sfere, a posljedica čega je bila da su se s vremenom sve više naglašavale eshatološke perspektive Kraljevstva.

\section{Božje kraljevstvo i misija}

Ako pretpostavimo da je Michael Barram $(2007,44)$ u pravu kad poziva na misiološko čitanje Biblije, onda bismo trebali moći prepoznati koncept Božjega kraljevstva kao dinamičnog, koherentnog i progresivno sveobuhvatnog misio $D e i$, koje zapravo oblikuje cijeli svijet, što onda, svakako, podrazumijeva i holističku perspektivu misije Crkve. Misija Crkve usko je povezana s missio Dei i kao takva je potpuno nespojiva s tradicionalnim uskoshvaćenim redukcionizmom. Kraljevstvo Božje osvaja / obuzima / prodire u svijet s namjerom prožimanja svega stvorenog na bezbroj načina izmirenja, a Crkva pritom treba reagirati centrifugalno u pronalaženju svoga puta ravno u središte problema ljudskosti. Biblijska se priča ne razvija prema uništavanju svijeta i našem vlastitom spasenju na Nebu. Vrhunac biblijske priče je obnova svega stvorenog u izvorno dobro stanje. 
Postoje neki posebni aspekti Božjeg kraljevstva koji bi Crkvi mogli biti od pomoći pri pokušaju razumijevanja okvira OR-a kao dostojnog angažmana kršćana. Najvažniji od njih je je, svakako, šalom (grčki eỉńvๆ, obično se prevodi kao mir), sveobuhvatni starozavjetni koncept koji se može opisati kao odsutnost sukoba, kaosa, ugnjetavanja i narušenih odnosa, štoviše kao dosljedna afirmacija cjelovitosti, pomirenja, dobrote, pravde, blagostanja te kao procvat svega stvorenog. Stoga, šalom nije puko stanje stvari, već dinamična, progresivna, kreativna, inovativna, umnožavajuća i centrifugalna snaga dobrote i blagostanja. Za njegovu je primjenu potrebna transformacija iz uobičajenoga ljudskog stanja sukoba i nemira u nešto što nam prorok Izaija majstorski ocrtava kao kompleksnu sliku novog oblika stanja ljudskosti koje je prije svega fokusirano na zavjetni odnos s Bogom i bližnjim (Iz 2,1-4) (Gorman 2016, 146-147).

Tekstovi Novog zavjeta ne govore puno o miru, a Gorman smatra da je posljedica te činjenice devastirajuća za život i misijsko djelovanje kršćanske Crkve (Gorman 2016, 144-145). "Blaženi mirotvorci! Oni će se zvati sinovi Božji." (Mt $5,9)$ predstavlja redak koji je toliko puno puta tijekom ljudske povijesti bio zanemarivan i krivo tumačen. Pavao razumije mir kao prvoklasni zadatak i praksu ecclesia-e, posebice ako je blisko povezan s ljubavlju i pravdom. Želi da njegove zajednice proaktivno prakticiraju mirotvorstvo kao svoj način života, a ne kao skup pukih apologetskih reakcionarnih mjera (Gorman 2016, 166). Kristoliki shalom treba, dakle, žurno i neposredno primjenjivati uvijek i svuda.

Vrsta solidarnosti predstavljena biblijskim konceptom zavjetne ljubavi (hebr. hesed), koju Walter Brueggemann $(2018,354$.) još naziva „uporna solidarnost“ izrasta iz zavjetne vjernosti i stvara „najdublju žudnju i glad, koji su elementarni za našu ljudskost“. Koncept OR-a zapravo se u potpunosti odnosi na voljno i svjesno održavanje zavjeta među strankama u duhu (političke) dobre volje, ali mu i dalje presudno nedostaje kreativna snaga i izvorna unutarnja logika Kraljevstva. Također, sam je jezik Gospodnje molitve posebno važan u upućivanju na Boga i njegovu suverenu intervenciju. Jednostavno ispunjavanje osnovnih dnevnih potreba je tu predstavljeno kao željeno / idealno stanje: hrana svima, otpušteni dugovi, mirna sigurnost. Ta kraljevska načela uključivanja, sudjelovanja, pravednosti i mira za sve sasvim dobro korespondiraju s paradigmom OR-a.

Kroz koncepte shalom i hesed, Božje kraljevstvo snažno korespondira s idejom OR-a kao temeljna pretpostavka realizacije postavljanih ciljeva, kao srž ljudske sudbine koja anticipira smislene perspektive za budućnost, kao jasna odrednica univerzalnog uspjeha čije se blagodati odnose na svakoga. 


\section{UN-ovi ciljevi održivog razvoja}

\section{Povijesni kontekst}

Koncept OR-a je proizašao iz brojnih problema očuvanja okoliša koji su se otvorili tijekom 20. stoljeća, no uglavnom je izveden iz Brundtland izvješća. ${ }^{8}$ Izvorna ideja da su zaštita okoliša i održivo upravljanje prirodnim resursima zajednička i žurna potreba cijelog čovječanstva tijekom posljednja tri desetljeća 20. stoljeća postupno je prerasla u paradigmu duboke promjene životnog stila suvremenog čovjeka. Bila je potaknuta sinkroniziranim naporima međunarodne zajednice, usmjerenim na oblikovanje održive budućnosti ljudi i planeta. Iako se izvorni koncept produbljivanja opće ekološke svijesti s vremenom sve više pomicao u sferu ekonomskog i društvenog razvoja, on je i dalje dosljedno usmjeren na harmoniziranje tri usko povezana temeljna elementa koji se smatraju ključnim za dobrobit čovječanstva i cijelog planeta: ekonomski rast, socijalna uključenost i zaštita okoliša.

Od vremena uznemirujućeg uvida Brundtland izvješća u sumornu budućnost čovječanstva pa do danas, međunarodna je zajednica poduzela nekoliko ključnih koraka na zajedničkom putu do suvremene Agende 2030, kojom se pretpostavlja ispunjenje 17 COR-ova. Jedan od prvih takvih koraka bila je UN-ova konferencija o okolišu i razvoju, takozvani Samit o Zemlji, organiziran 1992. u Rio de Janei$\mathrm{ru}$, na kojem su usvojene 3 ključne međunarodne konvencije. ${ }^{9} 178$ članica UN-a, među njima i Hrvatska, obavezale su se na dosljedno integriranje odrednica rečenih konvencija unutar svojih nacionalnih zakonskih okvira i dokumenata. Povelja o Zemlji je tada objavljena kao svojevrsni zaključak cijele konferencije, pri čemu je hrabro zacrtana putanja izgradnje pravednog, održivog i mirnoga globalnog društva 21. stoljeća. Iz ovog je političkog okupljanja na visokoj razini proizašla

8 Svjetska komisija za okoliš i razvoj (The World Commission on Environment and Development, WCED) objavila je 1987. izvješće pod nazivom "Naša zajednička budućnost" (Our Common Future). Taj je dokument postao poznat pod nazivom "Brundtland Report", a ime je dobio po tadašnjoj predsjednici Komisije, norveškoj liječnici i političarki Gro Harlem Brundtland. U izvještaju se hrabro istaknulo da su kritični globalni problemi okoliša prije svega posljedica ogromnog siromaštva svjetskog Juga te neodrživih obrazaca potrošnje i proizvodnje koji se primjenjuju na Sjeveru. Vidi: https://sustainabledevelopment.un.org/content/ documents/5987our-common-future.pdf.

9 Konvencija predstavlja pravni instrument koji je dogovoren na međunarodnoj razini i pravno obvezujući za sve potpisnice. Tri konvencije iz Rija, usvojene 1992. na Samitu o Zemlji: 1. Konvencija o biološkoj raznolikosti, 2. Konvencija UN-a o suzbijanju dezertifikacije i 3. Okvirna konvencija UN-a o klimatskim promjenama. Te su konvencije blisko međusobno povezane, primjenjuju se u istim ekosustavima te se bave međuovisnim pitanjima i problemima. Svrha im je da doprinesu ciljevima održivog razvoja koji su izneseni u dokumentu Agenda 21. Vidi: https://www.cbd.int/rio. 
zajednička nada da je međunarodna zajednica spremna i posvećena uložiti sve svoje sposobnosti i kapacitete u skladnu provedbu ciljeva OR-a. ${ }^{10}$ Također, treba naglasiti da su pristup informacijama, integracija i sudjelovanje javnosti pritom prepoznati kao ključne sastavnice i temeljni preduvjeti postizanja OR-a.

Svjetski su se lideri ponovno okupili 2000. u središnjici UN-a u New Yorku, kako bi usvojili Milenijsku deklaraciju UN-a. Utemeljili su novo globalno partnerstvo posvećujući svoje zemlje i narode aktivnom sudjelovanju u smanjivanju ekstremnog siromaštva u svijetu. Postavljen je niz vremenski ograničenih ciljeva, koji su postali poznati kao Milenijski razvojni ciljevi. ${ }^{11}$ Osam Milenijskih razvojnih ciljeva razvoja trebalo je postići do 2015., a to je u velikoj mjeri potaknulo još nikad viđene napore i mobiliziralo značajne svjetske resurse kako bi se zadovoljile potrebe najsiromašnijih ljudi na svijetu.

Svjetski su se čelnici potom okupili još jedanput u Rio de Janeiru 2012. na konferenciji UN-a Rio+20 o održivom razvoju, ali ovaj put uz puno sudjelovanje predstavnika civilnog društva. Svrha je bila procijeniti napredak koji je postignut u provedbi odluka dogovorenih 1992. i još jednom potvrditi potpunu predanost članica UN-a paradigmi OR-a. Svi su se složili da je za ostvarenje OR-a potrebno hitno djelovati kako bi se prevladali preostali nedostaci i pravilno suočilo s novim izazovima, a praktične mjere OR-a trebaju se dosljedno provoditi u duhu pravde, jednakosti, uključivosti, slobode, mira, sigurnosti i poštivanja svih ljudskih prava i ,temeljnih sloboda, bez razlike u rasi, boji, spolu, jeziku, religiji, političkom ili drugom mišljenju, nacionalnom ili socijalnom podrijetlu, imovini, rođenju, obliku invalidnosti ili nekom drugome statusnom određenju“. ${ }^{12}$ Pokrenut je proces oblikovanja novih COR-ova, koji će se temeljiti na iskustvu provedbe Milenijskih razvojnih ciljeva. Stvorena je strateška vizija programa za razdoblje nakon 2015. godine.

Konačno je 2015. godine u New Yorku održan samit UN-a za usvajanje razvojnog plana za razdoblje nakon 2015. Agenda 2030 za OR je oblikovana pod gordo skovanim nazivom „Preobražavajući naš svijet“ (Transforming Our World)

10 Ti su ciljevi tada formulirani u dokumentu Agenda 21 - akcijskom planu za održivi razvoj, na temelju kojeg su se zemlje potpisnice obvezale na neposrednu provedbu načela OR-a na globalnoj, regionalnoj, nacionalnoj i lokalnoj razini. Vidi: https://sustainabledevelopment.un.org/ content/documents/Agenda21.pdf.

11 Milenijski razvojni ciljevi su bili: 1. Iskorijeniti ekstremno siromaštvo i glad; 2. Omogućiti pristup kvalitetnom osnovnom obrazovanju za sve; 3. Promicati rodnu ravnopravnost i osnaživati žene; 4. Smanjiti smrtnost kod djece, 5. Poboljšati zdravstvene uvjete i zdravlje majki; 6 . Boriti se protiv bolesti poput HIV/AIDS-a, malarije itd.; 7. Osigurati održivost okoliša; 8. Graditi globalno partnerstvo za razvoj. Vidi: https://www.un.org/millenniumgoals/bkgd.shtml.

12 Dokument "Future We Want" (Budućnost kakvu želimo) dostupan je na https://sustainabledevelopment.un.org/index.php?menu=1298. 
kao plan djelovanja za ljude, planet i prosperitet koji ima za cilj konačno usmjeriti cijeli svijet na put dugoročne održivosti. Međunarodna se zajednica okupila kako bi svi zajedno krenuli dalje, uz obećanje da ovaj put nitko neće zaostati niti biti izostavljen. Nova skupina od 17 COR-ova i pripadajućih 169 ciljeva pokazuju univerzalnu ambiciju čovječanstva, koje konačno nastoji postići ono što se u dosadašnjem globalnom procesu nije uspjelo dosegnuti.

Vjerski čelnici iz cijelog svijeta također su tom prilikom potpisali izjave u korist mira, klimatske pravde i zaštite okoliša. Nadbiskup Bernardito Auza, apostolski nuncij i stalni promatrač Svete Stolice pri UN-u, smatra da je položaj Crkve u okviru ispunjenja COR-ova veoma jasan:

... snaga religija i njihova suradnja u poticanju miroljubivih i inkluzivnih društava počiva na njihovoj sposobnosti da osposobljavaju i ohrabruju proroke i lidere koji su u stanju potaknuti druge na konkretno djelovanje, razviti kod pojedinaca i zajednica osjećaj hitnosti te okupiti ljude za zajednički rad [u strpljenju i upornosti] za nešto što je veće od njih samih (Auza 2015, 12).

U tom su smislu ciljevi Crkve sljedeći: poticanje mira i inkluzivnosti, osposobljavanje budućih lidera za društvene transformacijske procese, inspiriranje konkretnoga društvenog djelovanja, razvijanje smislenog osjećaja žurnosti i ohrabrivanje na suradnju.

\section{Implementacija ciljeva održivog razvoja}

17 COR-ova čine samu srž Agende 2030. ${ }^{13}$ Oni predstavljaju hitan poziv na djelovanje u okviru globalnog partnerstva, poziv od strane svih zemalja, bile one razvijene, u razvoju ili nerazvijene. Svi oni koji su uključeni u proces njihove implementacije $^{14}$ jasno prepoznaju da borba protiv siromaštva treba istovremeno biti podržana nastojanjima unaprjeđivanja zdravstvenog i obrazovnog sustava, smanjivanja neravnopravnosti i poticanja ekonomskog rasta. Pritom je stalno potrebno konstruktivno se suočavati s izazovima poput klimatskih promjena, očuvanja stabilnosti, integriteta, kontinuiteta i raznolikosti kopnenih i vodenih ekosustava te njihovih usluga. ${ }^{15}$ Nadalje, rad koji se ulaže u razvoj zajednice dobi-

13 Vidi: https://sustainabledevelopment.un.org/?menu=1300.

14 Vidi: https://sustainabledevelopment.un.org/memberstates.

15 Koncept ekoloških servisa usvojen je 2001/2005. godine pokretanjem / objavljivanjem Milenijske procjene ekoloških sustava, studije koja je provedena tijekom razdoblja od četiri godine u 95 zemalja, a kojom su se pratili i procjenjivali učinci ljudske aktivnosti na prirodu. Usluge koje omogućavaju funkcionalni ekološki sustavi grupirane su u četiri osnovne kategorije: 1. Proizvodnju (engl. provisioning), primjerice hrane, vode, energije, sirovina, genskih, mineralnih, medicinskih resursa, i sl.; 2. Kontrolu (engl. regulating), primjerice korištenje ugljika, kontrola klimatskih procesa, proces razgradnje otpada, detoksifikacija i pročišćavanje vode i zraka, kontrolu širenja bolesti i štetočina, i sl.; 3. Podršku (engl. supporting) koja predmni- 
va sve više na važnosti: „prakticiranje vještina dobrosusjedskih odnosa, slavljenje sekularnih sakramenata građanskog zajedništva" (Block et al 2016, 63).

Za potrebe ovog istraživanja odabrana su tri specifična COR-a, koja će se pobliže razmatrati u svjetlu koncepta i načela Božjega kraljevstva, posebno s obzirom na kapacitet da stvori i održava dobrobit ljudi i svega stvorenog.

Tablica 1. 17 COR-ova

\begin{tabular}{|l|l|}
\hline Br. & COR \\
\hline 1 & Svuda bez iznimke iskorjenjivati sve oblika siromaštva \\
\hline 2 & $\begin{array}{l}\text { Iskorjenjivati glad, omogućavati sigurnost i poboljšavanje hranjivosti } \\
\text { namirnica, promicati održivu poljoprivredu }\end{array}$ \\
\hline 3 & Osigurati zdravlje i dobrobit za svakoga, bez obzira na životnu dob \\
\hline 4 & Osigurati kvalitetno obrazovanje i poticati cjeloživotno učenje za sve \\
\hline 5 & Postići rodnu ravnopravnost te osnažiti sve žene i djevojke \\
\hline 6 & $\begin{array}{l}\text { Osigurati svima dostupnost i održivo upravljanje pitkom vodom te omogućiti } \\
\text { primjerene higijenske uvjete }\end{array}$ \\
\hline 7 & Osigurati svima pristupačnu, pouzdanu i čistu energiju \\
\hline 8 & Poticati održivi gospodarski rast, zapošljavanje i dostojne uvjete rada za sve \\
\hline 9 & $\begin{array}{l}\text { Graditi kvalitetnu infrastrukturu, poticati održivi industrijski razvoj te } \\
\text { ohrabrivati inovativnost }\end{array}$ \\
\hline 10 & Smanjivati nejednakosti među ljudima, narodima i državama \\
\hline 11 & $\begin{array}{l}\text { Razvijati održive, pouzdane i sigurne gradove i naselja u kojima nema } \\
\text { marginaliziranih društvenih skupina }\end{array}$ \\
\hline 12 & $\begin{array}{l}\text { Osiguravati oblikovanje i primjenu odgovornih obrazaca potrošnje i } \\
\text { proizvodnje }\end{array}$ \\
\hline 13 & $\begin{array}{l}\text { Promišljati i primjenjivati konstruktivna rješenja problemaklimatskih promjena } \\
\text { i njihovih posljedica }\end{array}$ \\
\hline
\end{tabular}

jeva prirodne procese koji ekosustavima omogućavaju trajno i stabilno obavljanje osnovnih funkcija, primjerice omogućavanje odvijanja prirodnog ciklusa dušika, oprašivanje usjeva, i sl.; te 4. Kulturnu dobrobit (engl. cultural benefit), primjerice duhovna i društvena povezanost ljudi s prirodom, povijesni i tradicijski etno značaj, rekreacija, znanost, obrazovanje. Za svaku od usluga izvedena je odgovarajuća ekonomska vrijednost, koja se nadalje može koristiti u planiranju upravljanja i zaštite prirode, donošenju političkih odluka, oblikovanju legislative, promicanju odabranih društvenih načela, planova i programa. 


\begin{tabular}{|l|l|}
\hline 14 & $\begin{array}{l}\text { Poticati i dosljedno primjenjivati zaštitu i održivo korištenje oceana, mora i } \\
\text { svih njima pripadajućih resursa za OR }\end{array}$ \\
\hline 15 & $\begin{array}{l}\text { Provoditi zaštitu i obnovu te poticati održivo korištenje kopnenih ekosustava, } \\
\text { upravljati šumama na održiv način, boriti se protiv širenja pustinjskih područja, } \\
\text { degradacije tla i gubitka biološke raznolikosti }\end{array}$ \\
\hline 16 & $\begin{array}{l}\text { Primicati mirotvorstvo te prihvaćanje drugih i drugačijih, omogućiti lakši } \\
\text { pristup pravosudnom sustavu za sve i na svim razinama izgrađivati učinkovite } \\
\text { te vjerodostojne institucije }\end{array}$ \\
\hline 17 & Na svim razinama poticati i razvijati mrežu partnerstava za OR \\
\hline
\end{tabular}

U kontekstu osiguravanja zdravog života i promicanja dobrobiti za sve dobne skupine (COR 3), potrebno je uvidjeti kako, unatoč činjenici da je zdravlje milijuna ljudi znatno poboljšano, posebno u smislu produljenja životnog vijeka, smanjenja smrtnosti majki i djece te dosljedne borbe protiv bolesti prenesenih neposrednim kontaktom, još među ljudima i narodima raste osjećaj da se napredak ipak ne događa dovoljno brzo. Osim toga, stalno se otvaraju nova pitanja i problemi, posebno povezana s narušenim mentalnim zdravljem i kontinuiranim smanjivanjem antivirusne i antimikrobne otpornosti ljudskog organizma.

Čini se kako zdravlje svjetske populacije postaje još ranjivije povećanjem mobilnosti. Iako se veća mobilnost danas može smatrati privilegijom, ipak otvara mogućnosti za brzo širenje visokozaraznih virusa. Mnogi se nacionalni zdravstveni sustavi, čak i u razvijenim zemljama, suočavaju s velikim izazovima pri pravilnom prilagođavanju novim zdravstvenim okolnostima, posebno u smislu usmjeravanja migracija i okupljanja velikog broja ljudi. Stoga, paradigma OR-a ne pretpostavlja da zdravlje i dobar život moraju nužno uključivati veću dostupnost proizvoda i usluga. Kad se radi o zdravlju, zapravo trebamo govoriti o realnim očekivanjima i životnom stilu koji promiče umjerenost te uživanje u izvornoj jednostavnosti dobrih međuljudskih odnosa potpore i ohrabrivanja.

U kontekstu problematike oblikovanja održivih, pouzdanih i sigurnih gradova i naselja, u kojima nema marginaliziranih skupina (COR 11), iako se poticanje korištenja čistih izvora energije i načina transporta, zelene ekonomije, zeleno-pametnih stambenih jedinica, trajnog smanjivanja ekološkog utjecaja, lakšeg pristupa prirodi i otvorenom prostoru, lokalno proizvedene hrane itd. čini kao ispravna strategija, mnogo toga još uvijek mnogim ljudima i zajednicama nije dostupno. Dobro upravljanje gradovima i naseljima prvenstveno pretpostavlja predanost i otvorenost čelništva za promjene i prilagodbe suvremenim okolnostima te posebice sposobnost povezivanja vizionara različitih struka i provenijencija da djeluju zajedno na dobrobit sviju. Također, potrebna je istinska etika zajedništva te pro- 
gresivna upornost. Crkva se u tom okviru zasigurno može dobro pozicionirati i ponuditi društvenoj zajednici širok spektar praktičnih vještina, kao što su npr. organiziranje zajednice, razvijanje projekata, prikupljanje sredstava, poticanje interdisciplinarnog pristupa rješavanju problema, neposredan rad s beskućnicima i drugim marginaliziranim društvenim skupinama.

U kontekstu zaštite, obnove i promicanja održivog korištenja kopnenih ekosustava, što također pretpostavlja održivo gospodarenje šumama, suzbijanje nastanka i širenja pustinjskih područja, borbu protiv degradacije tla i gubitka biološke raznolikosti (COR 15), čini se da se kapacitet za skladan suživot čovjeka i prirode sve više smanjuje, posebno ohrabrivanjem mentaliteta koji je usredotočen na priznanje i uspjeh vidljiv kroz posjedovanje. Pitanja zaštite prirode i okoliša tradicionalno se rješavaju na marginama društvenog diskursa i prečesto samo u populističke svrhe. Iako Crkva tradicionalno zaštitu prirode i upravljanje resursima ne doživljava kao svoj prioritet, može na puno različitih načina svjesno i dosljedno promicati načela dugoročne održivosti među ljudima (razumna uporaba vode i energije, davanje prednosti korištenju lokalnih proizvoda i usluga, izbjegavanje korištenja predmeta i materijala koji se ne mogu oporabiti, poučavanje djece i mladih da vode brigu o okolišu, razvijanje ekološke svijesti u lokalnoj zajednici itd.). Premda se stopa gubitka šumskih bogatstava postupno usporava, iako se štiti sve više područja ključnih za biološku raznolikost te je sve više financijskih sredstava dostupno, degradacija zemljišta i dalje se nepovratno nastavlja, gubitak biološke raznolikosti se odvija alarmantnom brzinom, invazivne vrste brzo preuzimaju primat, nanoseći ozbiljnu štetu otpornosti ekosustava, a krivolov se nastavlja unatoč primjeni zakona.

Planiranje i djelovanje za OR zahtijeva razmišljanje i djelovanje izvan uobičajenih i tradicionalnih okvira. Interdisciplinarna je suradnja pritom od presudne važnosti. Ljudi trebaju biti sposobni čuti druge i drugačije, razumjeti i cijeniti drugost. No blisko poznavanje i razumijevanje društvenog i tehničkog konteksta također su od velike važnosti. Vrijedno je moći razmotriti i uzeti u obzir različite analitičke perspektive (političku ekonomiju, političku ekologiju, institucionalni razvoj, zajednička dobra, upravljanje itd.) te posebice razumjeti odnos između siromaštva i korištenja okoliša pri oblikovanju zajedničkoga društvenog stava i smislenoga akcijskog plana za budućnost. ${ }^{16}$

16 Za nadasve koristan uvid u dinamiku ovog procesa, vidi iskustva različitih studijskih skupina koje djeluju u okviru Udruženja studijskih programa za razvoj (Development Studies Association, DSA) https://www.devstud.org.uk/. 


\section{Diskusija}

Iako može biti veoma zbunjujuće da se najvažnije riječi Isusova rječnika izričito ne pojavljuju u Starom zavjetu, statistika u ovome konkretnom slučaju može zavarati. ${ }^{17}$ Bog, kao onaj koji vlada i rastjeruje zlo, predstavlja glavni lik svih psalama i drugih starozavjetnih tekstova. Gotovo je bezbroj referenci koje upućuju na Boga kao onoga koji vlada i kraljuje. Sigurd Griendheim $(2018,16)$ primjećuje da takav koncept prikazuje „Boga koji daje i dijeli život bogatstva, obilja i kvalitetnih međuljudskih odnosa. Bog daje život koji je bez srama, sukoba, ljubomore, zavisti, kompeticije, poniženja." Riječ je zapravo o kontekstu na koji se moderni kršćani trebaju oslanjati kada su sve uvjereniji u kreativnu snagu Kraljevstva, koja oblikuje i duboko utječe na našu stvarnost. Ipak, trebamo se složiti i s Deanom Flemmingom koji nas potiče na oprez kada želimo „dati prednost Novom zavjetu pred Starim, ili poticati model misijskog djelovanja koji je izričito ograničen na propovijedanje Evanđelja narodima“ (Flemming 2013, 46).

Živimo u vremenu stalnih promjena, često u okolnostima straha i bolne neizvjesnosti. Nove ideje neprestano dovode u pitanje tradicionalne institucije i prijete zastarjelim strukturama koje se raspadaju pred našim vlastitim očima. Kao što John Blewitt primjećuje, konvencionalne granice praktički nestaju u svim sektorima ljudskog života i proizvodnje, a tradicionalni nam autoriteti postaju sve manje jasni i relevantni. U svijetu u kojem partnerstvo i suradnja postaju nužnost, Blewitt je siguran da si nitko više ne može priuštiti bilo koji oblik izolacije (Blewitt 2008, 431). Destruktivna ponašanja, dubok očaj i nekontrolirano nasilje čvrsto su povezani s našim životima, a s istim su se okolnostima suočavali i naši preci. Često smo s pravom zbunjeni oko toga što je stvarno, a što nije. U tom je smislu Richard S. Hanson (1971, 11-12) još relevantan kada tvrdi da naša sposobnost razabiranja i razlikovanja između presudnog i beznačajnog, između trajnog i privremenog, između dragocjenog i bezvrijednog progresivno opada.

Imamo očajničku potrebu otkriti što nam zaista može pomoći da bismo živjeli dobar život i pritom napredovali. $U$ tom ćemo smislu nadalje pokušati sažeti dodirne točke dva ovdje razmatrana koncepta. Najprije ćemo pokazati kako Božje kraljevstvo i OR funkcioniraju u sinergiji, a zatim ćemo pokušati ukazati na ključne razlike među njima. Također, još jednom ćemo iskoristiti priliku i naglasiti važnost primjerenog oblika vodstva - kristolikog vođenja karakteriziranog milosrdnom nadom i iščekivanjem progresivne osobne, društvene, političke i ekonomske transformacije. Poglavlje ćemo zaključiti raspravom o mogućnostima primjene novostečenih uvida i perspektiva u kontekstu Crkve.

17 U tekstu Starog zavjeta postoje samo dvije reference koje se odnose na Božje (Gospodnje) kraljevstvo: 1 Ljet 28,5 i 2 Ljet 13,8. 


\section{Sinergije}

Dva koncepta, koji se ovdje detaljnije razmatraju, Božje kraljevstvo i OR, iako dolaze iz različitih izvora, gotovo $s$ jednakom razinom entuzijazma otvaraju isti skup univerzalno relevantnih pitanja. U kontekstu praktične primjene oba su koncepta posvećena pravilnom razumijevanju aktualnog trenutka u kojem se nalazi čovječanstvo i ljudska civilizacija, sve u svjetlu neposrednoga povijesnog iskustva te mogućih budućih perspektiva.

Na temelju sedamnaest odlomaka iz knjige proroka Izaije, Glen Stassen i David Gushee $(2003,25)$ prepoznaju sedam ključnih obilježja Božje vladavine: 1. izbavljenje ili spasenje, 2. poštenje / pravda, 3. mir, 4. radost, 5. Božja prisutnost kao Duh ili Svjetlost, 6. izlječenje ili ozdravljenje, 7. povratak iz stanja izgnanstva. Sve je to usko povezano s Agendom 2030 svijeta koji se trudi da ponovno uspostavi svoje izvorno blagostanje. U tekstu Rimljanima 14,17 vidimo da se Pavao također oslanja na Izaijine tekstove o Božjem kraljevstvu te upućuje na pravednost, mir i radost u Duhu Svetom. Matej piše o hranjenju gladnih, srdačnom prihvaćanju stranaca, posjećivanju bolesnih, obraćanju pozornosti djeci $(19,14)$, opraštanju dugova (18,23-35), mirotvorstvu, pružanju podrške društveno marginaliziranima $(19,12)$, izlječenju $(19,28)$, ali također i osjećaju radosti u nazočnosti Zaručnika $(13,34)$. Na isti način paradigma OR-a kao svoja temeljna načela ističe pravdu, mir, jednakost, društvenu stabilnost, sigurnost, prosperitet, ekonomski rast i socijalnu uključenost.

Oba se koncepta izrazito trude pravilno razumjeti potrebu i afirmirati okolnosti za postizanje dugoročne društvene otpornosti i prilagodljivosti. Također, oba visoko cijene svaki trud uložen $u$ dobrobit zajednice te $u$ smislena partnerstva. $U$ tom smislu, izgnaničko iskustvo drevnog Izraela, koje je prisililo ljude da preispituju svoje prioritete sa svrhom uspješnog preživljavanja i daljnjeg napredovanja, predstavlja za nas danas izuzetno važnu lekciju. S druge strane, istraživanja nedvojbeno pokazuju da gubitak otpornosti društva, koji je uzrokovan neodgovornim ponašanjem, neizbježno utire put katastrofalnim pomacima u ekosustavima i njihovim kapacitetima pružanja usluga, ozbiljno razvija svijest javnosti i usredotočuje društveni interes izrazitije na pitanja zaštite okoliša (Scheffer 2001, 592). Isto načelo vrijedi i za Božje kraljevstvo u kojem se dugoročna otpornost pojedinca i zajednice razumije kao čvrsto uvjetovana zavjetnom vjernošću i odgovornošću. Iako se političke i društvene odluke uglavnom oslanjaju na znanstvene dokaze i ekonomske argumente, koji su javnosti privlačni zbog svoje mjerljivosti i usporedivosti, ipak mogu dovesti do lažnih i pojednostavljenih rješenja ako ne uzimaju u obzir odgovarajuća etička načela (Peepre i Jickling 1994, 14).

Oba sustava razmišljanja i vjerovanja pretpostavljaju potrebu za cjelovitim holističkim pristupom upravljanju prirodnim, ekonomskim i društvenim resursima. Oba koncepta potiču kreativnost, inovativnost i „razmišljanje izvan okvi- 
ra“ unatoč činjenici da koriste različit izričaj. Ako bismo željeli postaviti Božje kraljevstvo unutar konteksta suvremenog svijeta, cjelokupna ideja OR-a ukazala bi nam se veoma smislenom, posebice zbog svoje društvene progresivnosti, biocentrične etičnosti, odstupanjem od idealiziranja tradicionalnih društvenih vrijednosti te spremnošću na razotkrivanje predrasuda. Ono što paradigmi OR-a izgleda da nedostaje za punu učinkovitost svojevrsna je božanska iskra u zajedničkoj viziji sadašnjosti i budućnosti cjelovitoga Božjeg stvorenja. Ta je božanska iskra predstavljena dosljednom afirmacijom darova Duha (Rim 12, 1 Kor 12, Ef 4 i 1 Pet 4), zapravo skupom univerzalnih vrijednosti koje se ne mijenjaju samo zato što svijet mora iznova preispitivati svoje prioritete uslijed promjene okolnosti. I ta ista božanska iskra, koja se toliko puta pokazala sposobnom potaknuti kreativnu vatru u ljudskoj sferi, zapravo jest ona koja osigurava održivost. Ova božanska iskra, koja dolazi iz Božjeg kraljevstva, neposredno se odnosi na održivost, no održivost koja očito ne pretpostavlja isključivo ekonomski razvoj kao preduvjet svake posljedične društvene dobrobiti. U tom smislu Brueggemann lobira za afirmaciju svježe perspektive u održavanju šabata kao alternative normativnom društvenom ponašanju (Brueggemann 2018, 223). Bez mogućnosti razmatranja i korištenja svježih perspektiva, koje osporavaju dominantne društvene norme, razvoj gubi šansu da bude univerzalno relevantan, pravedan, etičan, učinkovit i uključiv. Bez toga, cijeli razvijeni svijet ubrzano napreduje u propast, povlačeći sa sobom one druge s manjim kapacitetima za preživljavanje prema istoj neumitnoj sudbini.

Poticanje hrabre maštovitosti duboko karakterizira oba koncepta. U tom kontekstu, starozavjetni proroci i praktičari plave ekonomije ${ }^{18}$ stoje jedni pored drugih poput svjetionika. Riječi Andreasa Hernandeza (2018, 168-169) o potrebi preispitivanja naše duhovnosti pri poticanju iznalaženja novih društvenih praksi i oblikovanju novih priča i svjetonazora u procesu konstruiranja nove politike i ekonomije danas zvuče razumnije nego ikad.

\section{Različitosti}

Dva koncepta zasigurno se preklapaju i pretpostavljaju mnoga ključna sinergijska djelovanja, ali podrazumijevaju i neke ozbiljne razlike. Agenda 2030 promovira zdravlje i blagostanje u vrlo praktičnom smislu, a pritom se čini da su mjere prevencije najvrjedniji način suzbijanja širokog opsega štetnih oblika ljudskog ponašanja. No ne treba smetnuti s uma da su takva ponašanja uglav-

18 Plava ekonomija: 10 godina - 100 inovacija - 100 milijuna radnih mjesta knjiga je autora Guntera Paulia objavljena 2010. koja donosi mnogo inspirativnih primjera malih poslovnih modela, koji društvu donose mogućnost prelaska iz siromaštva u obilje. Svi navedeni modeli predmnijevaju korištenje lokalnih resursa i nude praktična rješenja problema vezanih uz neodgovorno postupanje prema okolišu i prirodnim dobrima. 
nom samo pokazatelji, a ne i uzroci jadnih životnih okolnosti i duboko narušenih društvenih odnosa. Takvi se odnosi, međutim, ne mogu učinkovito liječiti bez rastućeg osjećaja prihvaćanja na općoj i pojedinačnoj razini, kao i dubokog izmirenja između različitih društvenih skupina. Posebno je koristan način na koji Richard Clugson $(2015,35)$ određuje prioritete: „Naše etičke / duhovne leće kroz koje poimamo održivost omogućuju nam da razumijemo COR-ove kao koncepciju kvalitetnog življenja u kojem su ekonomski rast i široka ponuda potrošačkih izbora dobri samo ako omogućavaju puninu ljudskog življenja.“ Tako, primjerice, unatoč tomu da se COR-ovi 4, 5 i 10 bave smanjenjem nejednakosti (spol, obrazovanje, različite države), čini se da se ne bave rješavanjem nejednakosti koje su uzrokovane ekonomskim, etničkim, jezičnim, religijskim, stilom življenja i drugim socijalnim razlikama.

Isusove riječi zapisane u Mateju 4,4: „Čovjek ne živi samo o kruhu nego o svakoj riječi što dolazi iz Božjih usta" očajnički naglašavaju univerzalni problem pojedinaca te ljudskih društava i zajednica koji teže biti samodovoljni i koji nastavljaju zaboravljati da je život puno više od puke ekonomske sigurnosti i ekskluzivnog razumijevanja životne dinamike i sustava prioriteta koji Boga i bližnjega ne uzimaju dovoljno ozbiljno u obzir. Univerzalna ljudska potreba osiguravanja ugodne i praktične udobnosti često nam zamagljuje širu perspektivu stvarnosti. U tom kontekstu moramo biti svjesni činjenice da smo već učinili (i nastavljamo činiti) puno smrtonosnih pogrešaka, tako da bi samo opće javno pokajanje moglo donijeti duboko iscjeljenje. Biblija puno govori o ovoj korisnoj metodi društvenog izmirenja kao preduvjeta svakog blagostanja, ali svijet i dalje uporno oklijeva preuzeti punu odgovornost za svoje odluke i postupke.

Danas možemo puno naučiti iz povijesti socioekonomskog iskustva drevnog Izraela. Taj mali ekonomski sustav iz 8. stoljeća pr. n. e. vodile su društveno-političke elite u glavnim gradovima Samariji i Jeruzalemu. Sustavom oporezivanja i zemljišnim zajmovima s visokim kamatama izvlačile su bogatstvo iz rada seljaka poljoprivrednika. Iako je takav aranžman bio izrazito nepravedan prema seljacima, činilo se da je potpuno normalan te da mu je budućnost i trajnost zauvijek osigurana. Sve dok se „nekako neobjašnjivo“, kaže Brueggemann, nije pojavio niz međusobno nepovezanih pjesnika unutar različitih društvenih skupina, koji su se svojim javnim istupima usudili dovesti u pitanje cijeli ekonomski sustav koji je tada bio normativan $(2018,199)$. Ti su čudaci objavljivali emancipacijskog Boga, koji je blisko i do najsitnijeg detalja zainteresiran za političku ekonomiju društva. $\mathrm{U}$ ime zavjetne odgovornosti naroda prema Bogu, pozivali su na promjenu i duboko preoblikovanje važećega ekonomskog sustava (Brueggemann 2018, 205). Usred zastrašujućeg povijesnog konteksta, u kojem su djelovali, starozavjetni proroci su ipak glasno pozivali na pravdu, poštenje i svetost. Pozivali su doslovce na Dođi Kraljevstvo Tvoje. Kao što Brueggemann primjećuje, pokazivali su prstom 
na svaki nezgodni $z$ bog toga. ${ }^{19}$ Isti onaj $z$ bog toga s kojim se suvremeni svijet i dalje bori, a koji danas još glasnije odjekuje zbog široke dostupnosti pouka iz povijesti i dobro elaboriranih znanstvenih spoznaja. Danas se, dakle, suočavamo s posljedicama iste cinične eksploatacije koja se dosljedno događa već tri tisućljeća.

Usred dominantnoga suvremenoga svjetovnog mentaliteta, koji se često odlikuje ponosnom i pohlepnom samopromocijom, potragom za vanjskim uspjehom i samopravednošću, vrline ljudi Božjeg kraljevstva danas se mogu doimati prilično neobično, gotovo nastrano. Ljudske se slobode štite institucionalno, a zakoni nam određuju koje je primjereno društveno ponašanje. Kao što je tvrdio poznati hrvatski sociolog Ivan Cifrić, moderno društvo tako zapravo ukida etos i zamjenjuje ga različitim oblicima institucionalnog i / ili instrumentalnog sustava odgovornosti (Matijević 2015, 146). S druge strane, ljudi Božjeg kraljevstva, koje prorok Izaija slikovito naziva "hrastovima pravednosti“ (Iz 61,3), često se skandalozno razlikuju u svojoj etičnosti. Oni su „siromašni duhom“ pa žarko teže za više Duha; žalosno su svjesni svih propuštenih i razorenih odnosa, prilika, resursa i kairosa koji su izgubljeni zbog neznanja, nemara ili lošeg upravljanja; svojom poniznošću i krotkošću jasno odstupaju od samopromocije u samopravednosti. Ljudi Božjega kraljevstva gladno žude za pravednošću, milostivi su, suosjećajni i strpljivi pošto su svojim cjelovitim integritetom u stalnoj potrazi za Bogom. Ti mirotvorci su čak spremni i osobno ponijeti teret potlačenih, marginaliziranih i duboko beznadnih.

\section{Pitanje vodstva}

Biblija afirmira postavku da Zemljom (a isto se odnosi na sve prirodne resurse, bili oni obnovljivi ili neobnovljivi) treba upravljati na životvoran način. No htjeli mi to prihvatiti ili ne, taj poziv zahtijeva od nas usvajanje brojnih promjena budući da nas Božje obećanje plodnosti, množenja, obilja i blagostanja trajno poziva na dinamično promišljanje i preoblikovanje našega ekonomskog sustava (Brueggemann 2002, 191 i 196). Osnovna karakteristika transformativnog vodstva jest otvorenost na dinamično mijenjanje ili, biblijskim jezikom, raspoloživost da se bude Bogom oblikovan (Iz 64,8; Jer 18,1-11; Rim 9,21; 2, Kor 4,7) ili pak neposrednim krikovima svojih bližnjih.

Isusovo objavljivanje Božjega kraljevstva nije bilo izdvojeno iz konteksta kulturnih i političkih pitanja njegova vremena, već s njima blisko i neraskidivo povezano. Kako kaže Marcus Borg (1998, 270-271), ta povezanost nije bila samo negativna u smislu izazivanja i kritike već i pozitivna u smislu strastvene uključenosti u korporativni život zajednice. Isus je objavljivao i sam željno iščekivao duboku

19 Na hebrejskom וֹכל - često korištena formulacija kojom starozavjetni proroci (Izaija 49x, Jeremija $71 x$, Ezekiel 74x itd.) izražavaju nedvojbenu uzročno-posljedičnu vezu između postupaka ljudi i pripadajućih posljedica u kontekstu zavjetne odgovornosti Bogu. 
promjenu na osobnom, društvenom, političkom i ekonomskom planu. Temeljni problem paradigme OR-a mogao bi zapravo biti prilično mlak stav većine prema jasnoj potrebi za (radikalnim) društvenim promjenama, a najizrazitije je vidljiv kroz nedostatno afirmiranje transformativnog modela vođenja.

\section{Sudjelovanje u Božjoj misiji}

Kršćanstvo je intrinzično misijsko, posebice s obzirom na to da je Bog u misiji pomirenja cijeloga stvorenog svijeta sa samim sobom. Kroz ostvarivanje svoje misije, Bog svijetu poručuje snažno DA, ali istodobno i odlučno NE. Zapravo je cijela Biblija sama po sebi misijski fenomen (Wright 2013, 22). Ipak, Daniel Bosch (2011, 8-11) nam ukazuje na nekoliko osnovnih oblika novozavjetnih poslanja: Matej stvara i šalje učenike, Luka naglašava važnost prakticiranja oprosta i solidarnosti, a Pavao pak poziva na pridruživanje eshatološkoj zajednici. Svi su ti modeli vođeni društveno-političkim potrebama prvih čitatelja novozavjetnih tekstova. Bosch tvrdi da različiti modeli misijskog djelovanja oblikuju različite misijske teologije, ali se one nužno međusobno ne isključuju iako često mogu biti u proturječju.

Misija Crkve jest sudjelovati u ostvarenju Božje misije. Bog i njegovo stvorenje su u stalnom dinamičnom odnosu te se od nas očekuje da to poštujemo, ali ne i da se stvorenju klanjamo. S obzirom na raspolaganje zemaljskim resursima, mogli bismo se, dakle, složiti s Christopherom Wrightom $(2013,397)$ da smo s Bogom u odnosu vlasnik-korisnik te smo svakako odgovorni za postupanje s Njegovom imovinom. Način na koji tretiramo Zemlju odražava naš vlastiti odnos sa Stvoriteljem tako da nismo neodgovorno neutralni kada koristimo prirodne resurse, komercijaliziramo ih ili zloupotrebljavamo u svoju korist. U tom je smislu naša misija ,autorizirano djelovanje korisnika u skladu s uputama vlasnika" (Wright 2013, 404). Tako je, dakle, prema Wrightu, jednostavna biblijska tvrdnja da „Zemlja pripada Gospodu“ temeljna postavka o kojoj se ne može pregovarati, kako u smislu ekološke etike tako ni u smislu misijskog pouzdanja.

Dean Flemming $(2013,23)$ nas poziva da razumijemo kako je misija mnogo više od zadobivanja ljudi za Krista. Riječ je o demonstriranju pravednosti i milosrđa u društvu koje ga ne poznaje. Misija počinje (i završava) s Bogom, a misija Božjih ljudi je u cijelosti sudjelovati u ostvarenju Božje misije. Preklapanja između OR-a i Božjega kraljevstva jasno omogućavaju Crkvi da se duboko posveti prakticiranju šaloma i njegovanju heseda na način sudjelovanja u svjetskim procesima, bez gubljenja svoga izvornog identiteta. I to zalažući se za inkluzivnost, glasno lobirajući za socijalnu pravdu, brinući se o siromašnima i marginaliziranima te šireći ljubav, razumijevanje i suosjećanje za sve stvoreno. 


\section{Zaključak}

Dva koncepta koja smo razmatrali u ovom istraživanju, Božje kraljevstvo i OR, nisu nikada ni trebali biti razdvojeni. Iako dolaze iz različitih izvora, bave se istim skupom univerzalno važnih pitanja. Očito je da potječu iz različitih razdoblja, koriste drugačiji izričaj i vokabular, izviru iz veoma različitih društveno-političkih okvira. No, bez obzira na to, oba su koncepta vrijedna, njihovo je ispunjenje od najveće važnosti te oba pozivaju na duboku osobnu i društvenu preobrazbu, oblikujući pritom konkretna rješenja. Oba su izrazito kreativna i inovativna te predmnijevaju ogromni kapacitet mobiliziranja zajednica, naroda, nacija i resursa.

Božje kraljevstvo se prvenstveno odnosi na izbavljenje od prevlasti grijeha te kulture srama i krivnje, na jasne izglede za spasenje, na afirmaciju pravednosti za sve, na doživljaj mira i radosti u neposrednoj Božjoj prisutnosti, na iscjeljujuće i oslobađajuće iskustvo „povratka iz izgnanstva“. Ostvaruje se kroz različite aktivnosti kao što su hranjenje gladnih, iskazivanje dobrodošlice tuđincu, posjećivanje bolesnih, briga za djecu i druge marginalizirane skupine, praštanje dugova, mirotvorstvo, holističko življenje u prisnosti s Isusom koja rezultira uspješnim življenjem. Paradigma OR-a sa svoje strane pak preuzima osnovna načela pravednosti, mira, jednakosti, socijalne stabilnosti, sigurnosti, prosperiteta, zdravoga ekonomskog rasta i poticanja društvene uključenosti.

Oba se koncepta trude primijeniti pravilno razumijevanje potrebe za dugoročnom otpornošću i prilagodljivošću te dijele visoko poštovanje za rad u zajednici i potiču partnersko udruživanje. Oba uviđaju potrebu da se prirodnim, ekonomskim i socijalnim resursima upravlja cjelovito i odgovorno, oba naglašavaju važnost progresivnosti, kreativnosti i inovativnosti.

Božje kraljevstvo je dinamično u svom djelovanju. Bog djeluje, a mi pritom aktivno sudjelujemo usvajajući nove stilove života u smislenom služenju i poniznosti. Stalno se trebamo podsjećati da "je Isus ispunio vjekovnu nadu Izraela, ali to se nije zbilo na neki očekivani ili željeni način“ (Wright 2014, 182). U istom paradoksalnom smislu, paradigma OR-a teži za postizanjem prilagodljivosti i senzibiliziranosti na rastuće potrebe svih društvenih skupina, njegujući pritom kulturu suosjećanja i inkluzije.

Oba koncepta afirmiraju sličan niz vrlina iako se vrline ljudi Božjega kraljevstva mogu činiti čudnim, posebice ako ih promatramo kroz prizmu dominantnoga suvremenog mentaliteta. Iako je narcistički konzumerizam, relativističke svjetonazore, visoko vrednovanje osobne neovisnosti, iracionalno hvastanje pripadnošću odabranoj nacionalnosti, jeziku, rodu ili društvenoj skupini, ponosno oslanjanje na krute tradicije i predrasude, pohlepnost za javnim uspjehom i priznanjem, plitkost odnosa i samopravednost moguće pronaći među ljudima svih prostora i vremena, ipak se dominantni mentalitet modernog svijeta često oštro protivi etičnosti i životnom stilu Božjega kraljevstva. 
Božje se kraljevstvo odnosi na žudno traženje transformativnog vodstva Duha Svetog; na duboku svijest o svim izgubljenim odnosima, resursima i prilikama za učiniti dobro; na život u krotkosti i skromnosti uslijed uvida u širu i dublju stvarnost; na gladovanje i žeđanje za pravednošću; na milosrđe, suosjećajnost i strpljenje uslijed osobne i društvene cjelovitosti; na mirotvorstvo koje je spremno razumjeti i ponijeti iskustva potlačenih, marginaliziranih i obeshrabrenih; na spremnost za preispitivanje „normativnog“ društvenog ponašanja. Od nas se očekuje da Isusove riječi prenesemo u djela i tako sudjelujemo u Božjem kraljevanju na Zemlji i među ljudima. U tom si smislu Crkva zasigurno ne može priuštiti da se izolira od sekularnog svijeta.

U provedbenom kontekstu OR-a, uloga Crkve je osigurati da ovaj put nitko ne zaostane niti da bude izostavljen. No Crkva također mora marljivo raditi na proširivanju normativnog razmišljanja, posebno ako se radi o tako složenim i višedimenzionalnim problemima kao što su siromaštvo, očuvanje ljudskog zdravlja ili zaštita okoliša. Zato što je Isus tako činio! Iako bi iskustvo globalne borbe protiv pandemije COVID-19 moglo prisiliti različite svjetske zajednice da preispitaju svoje prioritete i stvore nove načine bavljenja svojom održivošću, Crkva treba i nadalje s pravom inzistirati na istom skupu vrijednosti Božjega kraljevstva: na ljubavi, suosjećanju, istini, pravednosti te nadi u konačno izmirenje s Bogom.

\section{Bibliografija}

Allison, Dale C. Jr. 2010. Constructing Jesus. Memory, Imagination, and History. Grand Rapids: Baker Academic.

Auza, Bernardito. 2015. "Religion and the Sustainable Development Goals." Dialogue \& Alliance 29 (1): 10-13.

Barram, Michael. 2007. "The Bible, Mission, and Social Location: Toward a Missional Hermeneutic." Interpretation 61 (1): 42-58.

Blewitt, John. 2008. Understanding Sustainable Development. Abingdon: Earthscan.

Block, Peter, Walter Brueggemann i John McKnight. 2016. An Other Kingdom: Departing the Consumer Culture. Hoboken, New Jersey: Wiley.

Borg, Markus J. 1998. Conflict, Holiness, and Politics in the Teachings of Jesus. London, New York: Continuum.

Bosch, Daniel. 2011. Transforming Mission - Paradigm Shifts in Theology of Missions. Special Edition. New York: Orbis Books.

Brueggemann, Walter. 2018. Tenacious Solidarity. Minneapolis: Fortress Press.

Brueggemann, Walter. 2002. The Land. Place as Gift, Promise, and Challenge in Biblical Faith. Minneapolis: Fortress Press. 
Chilton, Bruce. 1984. The Kingdom of God in the teaching of Jesus. Philadelphia / London: Fortress Press.

Clugston, Richard M. 2015. "Religion and the Sustainable Development Goals." Dialogue \& Alliance 29 (1): 31-38.

Dodd, Charles H. 1961. The Parables of the Kingdom. New York: Charles Scribner's Sons.

Dulling, Dennis C. 1992. “Kingdom of God/Heaven.” U: David N. Freedman (ur.). The Anchor Bible Dictionary. New York, London, Toronto, Sydney, and Auckland: Doubleday, 4931-4959.

Flemming, Dean. 2013. Recovering the Full Mission of God. Downers Grove: InterVarsity Press.

Gorman, Michael J. 2016. Becoming the Gospel: Paul, Participation, and Mission. Ch. 5. Grand Rapids: Eerdmans.

Green, Joel B. 2013. "Kingdom of God/Heaven." U: Joel B. Green (ur.). Dictionary of Jesus and the Gospels. Downers Grove: InterVarsity Press, 6563-6576.

Grindheim, Sigurd. 2018. Living in the Kingdom of God. Grand Rapids: Baker Academic.

Hanson, Richard S. 1971. Kingdoms of man and the kingdom of God. Minneapolis: Augsburg Pub. House.

Hernandez, Andreas. 2018. "Another Worldview Is Possible: Grassroots Social Movements and the 'Great Work." Journal for the Study of Religion, Nature and Culture 12 (2): 147-171.

Matijević, Dalija. 2015. "Ethics of Institutional Nature Protection in Croatia." Social Ecology: Journal for Environmental Thought and Sociological Research 24 (2-3): 145-172.

Peepre, Juri i Bob Jickling (urr.). 1994. Northern Protected Areas and Wilderness. Proceedings from a forum on northern protected areas and wilderness Whitehorse, Yukon November, 1993. Whitehorse: Canadian Parks and Wilderness Society and Yukon College.

Perrin, Nicholas. 2019. The Kingdom of God: A Biblical Theology. Grand Rapids: Zondervan Academic.

Powell, Mark A. 2011. HarperCollins Bible Dictionary. Revised and Updated, New York: HarperOne.

Scheffer, Marten, Steve Carpenter, Jonathan A. Foley, Carl Folke i Brian Walker. 2001. "Catastrophic Shifts in Ecosystems." Nature 413: 591-596.

Stassen, Glen H. and David P. Gushee. 2003. Kingdom Ethics: Following Jesus in contemporary context. Downers Grove: InterVarsity Press. 
Treat, Jeremy R. 2019. Seek First: How the Kingdom of God Changes Everything. Grand Rapids: Zondervan.

Wright, Christopher J. H. 2013. The Mission of God: Unlocking the Bible's Grand Narrative. Downers Grove: InterVarsity Press.

Wright, Nicholas T. 2014. Surprised by Scripture. Engaging Contemporary Issues. New York: HarperOne.

\author{
Dalia Matijević
}

\title{
A Sustainable Development Concept in the Light of the Kingdom of God
}

\begin{abstract}
In searching for answers about the actual relation between two apparently incompatible concepts: the Kingdom of God and the Sustainable Development (SD), we will try to put them side by side and use respective comparative findings, in order to see if they can work together and possibly benefit from each other. The aim is to better understand future perspectives that are opening for the church within the contemporary context. The two concepts considered in this research, the Kingdom of God and SD, are never supposed to be separated. Although coming from different sources, using different languages, and springing out from different socio-political contexts, they tackle the same set of universal issues; both are eagerly anticipated, their fulfilment is of utmost importance, they both call for profound personal and communal transformation, both are powerfully creative and innovative, and both have the capacity to mobilize communities, peoples, and resources. The intersections between the SD and the Kingdom of God create opportunities for the church to practice shalom and to nurture hesed in the world by encouraging inclusiveness, lobbing for social justice, carrying for the poor and marginalized, and extending love and compassion onto the whole of creation, without losing its genuine identity. Within the SD framework, the role of the church is to make sure that nobody is left behind. The church might be the best part of the SD practice by persistently insisting on the same universal set of Kingdom values no matter how circumstances are changing.
\end{abstract}

